\title{
A new Swedish model? Swedish social democracy at the crossroads
}

\author{
Dimitris Tsarouhas
}

\begin{abstract}
Introduction
Sweden has for a long time been viewed as a paradigmatic case for progressive politics. Swedish social democracy, to which the progressive character of such politics was attributed, could legitimately claim to have mastered the historic task of the revisionist Left: building a societal coalition around the goal of enhancing social welfare for all, while safeguarding the profitability of business and delivering economic growth. When economic crisis hit home in the early 1990s, accompanied by the loss of power to a resurgent centre-right, the Social Democratic Party (SAP) was left vulnerable to accusations of a neo-liberal transformation (Ryner 2002) and specific attacks on abandoning the goal of full employment or the wage politics of solidarity, earlier practised by the social democratic trade union confederation known as the LO. Meanwhile, the Swedish model of industrial relations premised upon social partner autonomy, industrial peace and high-level coordination between the LO and employers (SAF) had given way to wage-bargaining decentralisation, the withdrawal of the social partners from state boards and agencies and growing divisions within the labour movement. The ensuing crisis was therefore not merely about the electoral prospects of the SAP. It actually touched upon the fundamental premises upon which the Social Democrats had built their welfare coalition, thus jeopardising the prospects for recovery once the SAP was re-elected.

This chapter examines the evolution of the Swedish model in conjunction with social democratic reformism and the party's relations to the union movement. The starting point of the analysis is the organisational and institutional bond between the SAP and the LO that flourished during the golden age of welfare capitalism and was severely tested in the 1980s. The main argument of the chapter is twofold. First, I show how the collapse of the old Swedish model has not led to the disempowerment of the trade union
\end{abstract}


movement. A new pattern of policy harmonisation has emerged following the signing of the Industrial Agreement (IA) in 1998. This could now be used as a catalyst from which a new Swedish model, befitting the globalised and Europeanised reality of Swedish policy-making, could potentially emerge. Second, and equally importantly, show that powerful challenges to the continued relevance of the labour movement in Swedish policy-making are currently in operation. Internally, the centre-right coalition government's labour and trade union laws diminish the power of organised labour. Externally, a recent ruling by the European Court of Justice may have longterm implications for the viability of the Swedish model.

The chapter begins with a brief discussion of the collapse of the old Swedish model, before examining the Third Way of the 1980s. The next part goes on to present the empirical evidence in support of the emergence of a new Swedish model, and underlines the importance of the SAP-LO partnership in allowing the union movement to play an influential role in the labour market. The chapter then explains the internal and external challenges for the labour movement, and the conclusion summarises the main argument, before offering some preliminary thoughts on the future of social democracy in Sweden.

\section{The collapse of the old model: causes and explanations}

By the early 1980s, the Swedish model was in crisis. Changes in the labour market, the reorganisation of production and the failure of the wage-earner funds meant that the ability of the labour movement to secure welfare in return for growth was in doubt. The crisis also tested the unity of the labour movement, pitting party against unions on a number of occasions.

\section{New labour market actors}

From the 1960s onwards, new actors sat at the negotiation table. The growth of the white-collar confederation, TCO, broke the previous LO monopoly in representing employees. A shift from blue-collar to service employment further strengthened the TCO position. From the 1950s to the 1980s, the percentage of workers employed in manufacturing industry dropped from around 40 per cent to only 20 per cent (Whyman and Burkitt 1993: 605). A consequence of the rise in white-collar professionals was the undermining of intra-union solidarity. Also, public sector employment increased sharply after the mid-1960s, and by the end of the 1980s the state employed almost one out of three workers. The increase in the influence of public sector employers and unions altered the distributional equilibrium and offered little incentive to private employers for continuing with centralised negotiations. 


\section{Employment legislation and the wage-earner funds}

The smooth functioning of the Swedish model was premised on the implicit acceptance of the labour movement of the veto power that business retained regarding economic development. For the Social Democrats, collaboration with business had always been a sine qua non for the pursuit of welfare politics. From the late 1960s, employee dissatisfaction with the workplace and ideological radicalism pushed the trade unions to the left. The LO embarked on an offensive which culminated in the wage-earner funds initiative, leaving it exposed to a counter-offensive by employers in the 1980s.

When the unions failed to gain the consent of employers on democratising working life, they resorted to legislation. The SAP introduced new laws to please the LO and demonstrate the party's socialist credentials. The Employment Security Act (Lagen om Anställningsskydd - LAS), the Work Environment Act and the Co-Determination Act (MBL) are the best examples of that drive of the 1970s. The committee instructed to look into the issue of capital increase and the democratisation of working life also submitted its report to the 1976 LO Congress. The report suggested that firms employing more than fifty employees should be required to issue new shares to an 'equalisation fund' corresponding to 20 per cent of their pre-tax profits. Trade union representatives would administer the fund; after twenty to thirty years, unions would own most of the profitable Swedish enterprises.

In 1983, and after successive committees had modified the original plan, the SAP government legislated on the issue. The watered-down law provided for five funds run with union representation. The payroll tax financing the funds was reduced to 0.2 per cent and their build-up period was limited to seven years. A 20 per cent levy on real profits was introduced and the law underlined the function of the funds as portfolio investors, with an obligation to show a minimum 3 per cent return on their investment. No single fund could own more than 8 per cent of a company's shares. By the time legislation was introduced, moreover, opposition had grown enormously, and in 1991 the centre-right government was able to abolish the funds entirely.

\section{Flexible specialisation}

Flexible specialisation also undermined intra-union solidarity, challenging the hold of the LO over its constituent unions. "The widespread application of numerically controlled, multipurpose machinery during the 1970s and 1980s led to a shift away from standardised mass production ...' (Iversen 1996: 406). Taylorist principles reached the limits of their effectiveness. They were replaced by a mode of production emphasising the 'responsible autonomy' of workers. 
The reorganisation of work was greeted by Swedish employers in the engineering sector as an opportunity to embrace flexible production techniques. However, the existence of the solidaristic wage policy practised by the LO since the 1950s meant that non-standard forms of payment were inhibited, posing a competitiveness risk resulting from the failure to attract high-skilled labour (Pontusson and Swenson 1996: 236). In a similar fashion to the engineering employers, engineering unions resented the fact that public sector unions were living off their productivity-based wage increases through the phenomenon of wage drift. Bound by the Confederation's solidaristic wage policy, skilled workers saw their relative pay position worsen compared to white-collar colleagues. Furthermore, the balance of power within the LO shifted in line with public sector expansion: in 1978, 'the traditional dominance of the metalworkers . . . was displaced by the largely female Municipal Workers' Union' (Callaghan 2000: 125). Under these conditions the process of decentralising collective bargaining gathered pace. The Engineering Employers' Organisation (Verkstadföreningen - VF) and its LO union counterpart Metall ceased to practise centralised bargaining in 1983, having agreed to wage increases higher than those negotiated centrally between the LO and SAF.

\section{The Third Way and the 'war of the roses': crisis contained}

The Social Democrats launched the 'Third Way' economic policy programme in 1981. The new approach called for a reappraisal of economic policy and the elimination of the current account deficit. To restore lost competitiveness, the economy had to transfer resources to the private sector (SAP 1981). The SAF was particularly pleased with the new approach of targeting inflation and removing the indexation of wages. However, the SAP continued to defend full employment and a strong welfare state (SAP 1985). At the same time, the LO was asked to accept lower budget deficits and a smaller public sector. The state in general and public spending in particular ceased to be seen as solutions (as they had been during the post-war boom) in public discourse and became instead the most frequently cited problems that needed to be addressed (J. Andersson 2006). The union-party clash that ensued included fierce disagreements over welfare reform and especially privatisation schemes. Public sector unions were particularly vocal, accusing the party of treachery and a disregard for members' interests. ${ }^{1}$ The austerity measures introduced after the 1988 election (including the reduction of sick pay rates from 90 per cent to 65 per cent for the first three days and to 80 per cent from day four up to ninety days' absence), meant that the SAP fell to 37.7 per cent in the polls in 1991, and a new government headed by the Conservative Prime 
Minister Carl Bildt was sworn in. By that time, the SAP had declared low inflation to be the party's main priority, instead of full employment. In 1990, the SAF appointed a new chairman, Ulf Laurin, distinguished for his antipathy towards the Saltsjöbaden 'spirit'. Upon taking the decision to dismantle the SAF Negotiations Unit in February 1990, Laurin proudly proclaimed the death of the Swedish model. Following the self-imposed termination of peak-level negotiations and having achieved a significant amount of policy change during the 1980s, the SAF called for coordinated decentralisation and plant-level wage bargaining.

In the 1994 pre-election campaign, the SAP vowed to ease off the pressure on state finances and reduce the high deficit through budget cuts and tax increases. This led to sceptical reactions by domestic and international capital, which enjoyed a high degree of independence from government policies, and did not feel bound to the old compromise with social democracy. The SAP proposed a four-year crisis package combining a 5 per cent 'recovery tax' on high earners, a rise in national insurance contributions and the lifting of municipal tax ceilings with cuts in foreign aid, refugee assistance, student grants and child pension and invalidity payments (Burkitt and Whyman 1995: 32). In a direct appeal to sceptical LO members, the SAP vowed to increase employment by 100,000 in four years.

The decision by Finance Minister and later Prime Minister (19962006) Göran Persson to cap public expenditure did not go down well with the LO and SAP supporters. The changes in the social insurance and labour market rules instigated by the Bildt government continued, and many of its social insurance reforms remained intact (Swank 2002: 139). Disgruntled voters switched to the Vänsterpariet (which may be literally translated from Swedish as the Left Party), which in 1998 became the third largest party in Parliament. In that year's election, 20 per cent of LO members voted for the Left Party, compared to a mere 4 per cent in 1991 (Möller 1999: 266). SAP ended up gathering a mere 36.5 per cent of the vote, a new low.

During the next two parliamentary terms (1998-2002, 2002-06) the SAP sought to consolidate its position at the heart of the Swedish political system and regain the trust of voters. It sought to do so by curbing unemployment and protecting the universal character of the welfare state through the initiation of measures such as a cap on childcare fees. Accelerating economic growth at the end of the 1990s meant that unemployment fell to about 4 per cent in 2001 (OECD 2001: 3). Having campaigned on the basis of preserving and extending the welfare state, the Social Democrats increased their vote share to 39.9 per cent in 2002 and remained in power with the support of the Left and the Green Party. 


\section{The Industrial Agreement and beyond: a new Swedish model?}

The collapse of the old Swedish model had three major consequences. First, it removed the foundations of the 'welfare-in-return-for-growth' exchange between social democracy and business. Second, it permitted the articulation of a coherent business doctrine that mounted a massive challenge to the old consensus. Finally, it threw Swedish social democracy into a long period of crisis and self-doubt. The collapse of the model questioned the ability of the SAP to steer the system in favour of the 'many' in conditions of rising complexity, and it led to the deterioration of relations between the party and the LO. It also threatened to remove the hold of Swedish social democracy over policy ideas by removing the basic principles of its function, and by dealing a fatal blow to its ability to deliver economic dynamism with social cohesion. Developments after the mid-1990s and especially since the early 2000s, however, signify that far from being just another case of 'organized decentralization' (Traxler 1995), the Swedish labour market is characterised by a high degree of continuity with the past. Combined with a discernible improvement in the party-union relationship, the prospects for a new Swedish model offer the chance for the articulation of a new progressive image of the good society.

\section{The role of the social partners}

The SAF's organisational restructuring in the 1990s did not transform its role. The principle of negotiation established in Saltsjöbaden was left untouched during the restructuring process. Collective agreements have continued to inform the logic of labour market action for employers. The SAF also retained the principle of insurance; additionally, the imposition of heavy fines on companies that did not abide by SAF directives continued through the mid-1990s (Pestoff 1995: 173). The exceptionally strong sense of collective action espoused by Swedish business remained intact. The amalgamation of the SAF and SIF to create the Confederation of Swedish Enterprise (Svenskt Näringsliv - SN) in 2001 hardly changed that collectivism:

In the statutes of the Confederation of Swedish Enterprise it says that the Board of Directors decides on the goals of the bargaining round for all member associations ... the level of compensation paid to members hit by industrial action is based on the way [they] have executed their obligations to inform and consult during negotiations. ${ }^{2}$

The best proof of SN centralisation came in 2007. When the Swedish Trade Federation (Svensk Handel) yielded to demands by its union counterpart for high wage increases, SN threatened action against its member and called 
for intervention by the Mediation Institute to resolve this particular intraemployer conflict. Faced with the prospect of a costly and embarrassing conflict, SN gave in (Dagens Nyheter 14 April 2007).

On the part of the LO, the initial response of the Confederation to the shift of the 1990s was to support measured change. An appreciation of individualised and flexible wage systems, it was argued, would encourage workers to update their skills and achieve professional advancement (LO 1991). At the same time, the LO was prepared to accept the need for change regarding the role of its member unions, who would now be called on to assume greater responsibilities. An LO report of 1992 sketched out what was later to become the LO's prime function: coordinating the wage demands of unions and setting the framework of their negotiations. The report also called for an emphasis on reducing the pay differentials between men and women (Johansson and Magnusson 1998: 339), a policy that became a prominent part of LO thinking by the late 1990s. However, not all unions endorsed the 1993 proposal for the LO to retain a coordinating role in wage bargaining. Metall suggested curbing public sector calls for compensation, but unions such as Kommunal did not necessarily share this view. 'The role of the LO has been questioned by all sections of society, even from our own members. They were not sure whether the LO should have a role in wage bargaining ... it was really an open question'. ${ }^{3}$

While deciding to retain the principle of solidarity in a way acceptable to all members, the LO emphasised that economic growth would increase the living standards of all members, and that economic policy should keep inflation at an average European level. By the time of its 24th congress in 2000, the LO asserted that 'the new politics of solidarity' had four functions: (a) full employment; (b) real wage increases for all and slightly higher rises for the lowest paid; (c) just distribution; and (d) work development (LO 2000: 744).

\section{Wage bargaining: from decentralisation to coordination}

The shift to a lower level of bargaining has not been accompanied by the realisation of all the changes envisaged by employers. Increased crossoccupational collaboration became part of labour's strategy to prevent the development of enterprise unionism and retain industry-wide bargaining (Thelen 1993: 47).

The Industrial Agreement (IA) of 1998 sprang out of the need for closer collaboration between blue- and white-collar workers in the face of industrial change, and the recognition that the export sector should remain the pace-setter in wage development. Trade unions in manufacturing industry led by Metall inspired a broad dialogue encompassing employer 
organisations and trade unions to provide a framework for collective bargaining. In March 1997, the IA was signed by twelve employer organisations and seven trade unions. The reinvigoration of a spirit of collaboration between employers and unions is mediated by the realisation that enhanced competition and the Europeanisation of Sweden's labour market poses new challenges regarding competitiveness and the maintenance of high pay and working standards.

The Agreement set out to offer a new mode of regulating the labour market by concentrating on the need to avoid industrial action for as long as possible, promoting industrial development and enhancing profitability to secure sound wage development. The labour market partners agreed on the establishment of an industrial committee, which would have the power to intervene in the negotiations at an early stage. The IA was tested in the bargaining round of 1998 for the first time and turned out to be a success. All timetables were kept, industrial action was not contemplated and the wage levels agreed became the norm for the rest of the labour market (Elvander 2002: 130). What is more, the Industrial Agreement reconfirmed the 'spirit of Saltsjöbaden', in that unions and employers agreed on the need to avoid state interference in collective bargaining. With regard to the level of bargaining, decentralisation and local negotiations became the norm in a series of collective agreements. Local partners assumed responsibility for the level and distribution of wages. However, the prerogative of employers to set wage levels according to their preferences was curbed due to 'cut-off' provisions that specified wage increases as well as, in many cases, the minimum wage increase for individual workers.

Following a series of earlier failures to coordinate its affiliated unions, the LO has met with considerable success since the early 2000s. Before the start of the 2001 bargaining round, it made a series of suggestions to its member unions regarding minimum pay increases and the above-average wage increases that should be awarded to the lowest paid (LO 2001: 4-5). Despite the special arrangement that LO unions have with white-collar and professional engineering unions, all LO unions were bound by the accord and agreed to its recommendations. The same procedure was followed in 2004. The role of the LO was now more pronounced, as individual unions did not make amendments to the text agreed at confederal level. The chief coordinator of the $\mathrm{LO}$ for the 2004 round described the latter as 'the most centralised [round] I have been through'. ${ }^{4}$

Finally, the 2007 bargaining round was characterised by the LO's decision to secure higher wage increases for its female members, most of whom are organised in Kommunal. The gender-neutral attempts to implement such a policy had met with little success in the past, and about 90 per cent 
of female LO members belong to the lowest-pay scale. Although Metall put up a fight against increases targeted at women, it succumbed to collective pressure and abided by the coordination demand. The export-oriented sector functioned once again as a pace-setter, and both Kommunal and Metall concluded collective agreements that can boost the wages for the lowest paid, thus confirming the salience of LO coordination (Dagens Arbete, 19 March 2007). What is more, the Kommunal agreement with employers in the municipal sector now includes an equality pot that can potentially reduce wage differentials in a way that has not been achieved since the 1990s. On the other hand, the 2007 bargaining round also revealed the first serious cracks in the IA structure, as Handels and Kommunal secured wage increases above the levels prescribed by the IA agreement. Still, successful coordination over the last few years has led the LO to request authorisation for a formal coordination at its 2008 congress.

In the early twenty first century, the social partners retain a key role not only in regulating the labour market, but also in complementing statefinanced welfare. The LO and Svenskt Näringsliv came together in two supplementary agreements, on sick pay (Avtalsgruppsjukförsäkring-AGS) and an insurance scheme against job loss (Avgångsbidragsförsäkring-AGB). The two sides have created a co-owned company, AFA, responsible for insurance against death, work injuries, illness and redundancy. The company has calculated that about three million people are insured against at least one of these risks with AFA. In addition, the LO and Svenskt Näringsliv have created a safety foundation (Trygghetsfonden - TSL) to support employees who have recently been made redundant. Statistics show that 85 per cent of those benefiting from TSL funds had found a new job in 2006 (TCO Tidningen, 8 March 2007). Finally, a revised pension agreement between the LO and SN was signed in 2007 equalising pension conditions for LO members with those of white-collar employees (TT, 16 April 2007).

\section{Institutional resources}

The highly uncertain 1990s have been replaced by a challenging but more predictable framework of operation for the Swedish labour movement. A key factor behind the continued ability of organised labour to influence the public policy debate is the high union density rate, which stood at 77 per cent in 2006. The growing influx of migrant labour in the 1990s could pose a serious challenge to unionisation rates, assuming that the 'union culture' of Sweden is much weaker in other parts of the world and particularly outside Western Europe. Nonetheless, a 2004 LO report showed that women originating from non-European countries had a rate of unionisation as high as 74 per cent, and most of them belonged to a union affiliated to LO (LO 2004). 
The centralisation of industrial relations in the early twentieth century meant that firm-by-firm struggles were largely avoided and "extensive union access to workplaces helped maintain rank-and-file contact and organize workplace bargaining' (Kjellberg 1998: 617). The ability of both unions and employers' organisations to centralise and gain access to places of work is not a fortunate coincidence. It is derived from the historical character of the Swedish state and the concomitant emergence of industrialisation and democratisation that facilitated the growth of strong unions as part and parcel of a democratising polity, with a strong labour movement consolidating its strength in the absence of a coherent conservative counter-force. Added to that is the Ghent-type unemployment insurance funds, offering trade unions control of the funds' administration. Although successive reforms of the funds have rendered union powers weaker, organised labour continues to exert a heavy influence on the running of the funds. The 1930s initiative by the SAP to create a Ghent-type system has rendered very practical, long-term results in terms of trade union strength.

Finally, relations between the SAP and the LO have improved steadily after their low point of the 1990s and are seen as highly cooperative and effective by both sides. ${ }^{5}$ The Europeanisation of Swedish politics, and the influence of the common stance of the SAP and LO on EU issues, has played an important role in this process. The power and influence of the trade unions remains decisive in the process of decision-making for the Social Democrats. To give but one example, in 2004 the government agreed to reform LAS legislation after union pressure. The new piece of legislation would prioritise fixed-term workers in moving to open-ended employment contracts, and offer them the opportunity to be reclassified as open-ended employees under favourable conditions. It is through such measures that the earlier public sector union grievances have diminished, and LO financial and organisational resources are put at the disposal of the party machinery prior to electoral contests.

\section{Contemporary challenges: the 2006 election and the Europe factor}

\section{The 'Alliance for Sweden'}

Judging by the historical record, the chances of the Social Democrats winning yet another election in 2006 were very high indeed. Every time they had lost power before, the economy was in trouble and the party's ability to guarantee prosperity was in serious doubt. In 2006, however, the economy was booming and public finances recorded a healthy 3 per cent surplus (Aylott and Bolin 2007: 621). Not much seemed to be going wrong.

What did go wrong, however, was the impression or (according to some) 
the fact that Sweden suffered from 'jobless growth'. The subject of continuous controversy well before the election campaign, the rate of unemployment was making headlines for months, as the government claimed much lower rates of unemployment than the ones reported by international organisations. The opposition was quick to accuse the government of misleading the public and eventually managed to persuade voters that the SAP was unable to offer solutions to the problem. In combination with a slow trickle of minor scandals which dented the reliability of key ministers and the objectivity of civil servants, the belated recognition by the SAP that employment constituted the main campaign issue was unable to avert defeat, handing over power to a resurgent centre-right coalition, the 'Alliance for Sweden'.

The new government was soon marred by controversy, and the initial honeymoon usually afforded by voters to incumbent governments vanished. The government's main problem has been its welfare reform programme, not least its changes in the unemployment insurance scheme. Adopting a workfare approach to welfare and claiming to defend the welfare state, the government maintains that its reforms merely aim at making existing welfare structures work better. The one-time neo-liberal Moderate Party denies that it intends to reform labour law or hamper the Swedish model. There are important reasons to doubt the sincerity of such claims, at least regarding their consequences for the trade unions.

The government introduced a series of amendments to the unemployment insurance scheme with regard to eligibility, levels of compensation and the financing of insurance. Membership fees are set to increase to a maximum of SEK 300 for employed people, and insurance funds will have to bear one-third of the overall costs to support 'their' unemployed members. The eligibility threshold to qualify for the benefit will increase from 70 to 80 hours per month for six months out of a total of twelve months. Finally, compensation levels will progressively decrease from 80 per cent of gross earnings for the first 200 days to 70 per cent after 300 days and to a maximum of 65 per cent thereafter, upon participation in a new job and development guarantee scheme.

The consequences of these changes are very significant. Apart from the lower 'take-home' compensation, the change in financing of the system is likely to undermine intra-fund solidarity by pitting funds with lower unemployment levels against those with higher levels. State financing of the funds will go down from about 90 per cent in 2005 to 56 per cent after the changes are introduced. The LO has also calculated that after-tax earnings from unemployment insurance after 300 days of unemployment will reach the (much lower) levels of social assistance in the coming years (Dagens Nyheter, 17 November 2006). The question then becomes whether 
the intention of the government is to boost employment levels by indirectly forcing the unemployed to accept lower wage standards. The LO is more likely to be hit by such measures, as unemployment among LO members is higher than for other occupational categories.

As the unions had predicted, a massive exodus from the unemployment insurance system has followed the introduction of the reforms. About one in ten members have left the system during 2007 (Dagens Nyheter, 13 December 2007). Not least due to decreasing revenues following lower participation, the government's most recent response has been to propose making unemployment insurance membership obligatory. Unions and employers, for very different reasons, agree that the current system of optional membership should be preserved (Svenska Dagbladet, 22 October 2007).

At the end of 2007, the government announced a new set of welfare proposals. The envisaged reform increases unemployment insurance qualifying days from two to seven, limits receipt of unemployment benefit to seventy-five days for part-timers and to eight months for the unemployed, decreases sickness benefits and abolishes the SAP reform which would have obliged employers to co-finance sick leave for full-time employees (EIROnline, 2007). The SAP reform to ease moving from fixed-term to permanent employment has also been hindered by legislation facilitating fixed-term employment. Finally, the government's proclamation on the desirability of maintaining the Swedish model has been subjected to intense criticism from the SAP, LO and TCO following its proposals to block agreements by the social partners guaranteeing higher replacement rates for long-term sick employees compared to the state benefit. Since such agreements are reached through collective agreements, SN has also come out against such a reform (Dagens Nyheter, 22 December 2007).

Although a declining trend in union membership has been observed over a number of years, this decline was gradual and the organisation rate of Swedish unions remained very high. Recent data paints a picture of dramatic union membership decline, parallel to the mass exodus from the unemployment insurance system. As of December 2007, the unionisation rate stood at 72 per cent, a 5 per cent decline in a year, which means that the density rate is now at 1970 s levels. Although rising employment levels provide a plausible explanation, the centre-right's decision to abolish the tax-deductible status of union membership did little to boost union membership.

The centre-right government's workfare approach seriously affects the viability of the Swedish model. The decline in unionisation, if it continues, means that Sweden's unions will lose their main weapon of legitimacy. A union movement that ceases to be mass-organised will have less of an 
impact on the labour market, and will be less likely to steer employers towards mutually acceptable outcomes. Weaker unions will have less of an impact on elections, ceasing to mobilise workers in favour of the SAP. In turn, the Social Democrats' dependence on the unions will lessen, and this is likely to translate into yet more 'centrist' positions, disregarding the agenda of the labour movement. In other words, the consequences of the 2006 elections could have a long-lasting negative effect on Swedish social democracy.

\section{The Vaxholm conflict}

In December 2007, the European Court of Justice (ECJ) ruled that a blockade by trade unions led by the Construction Workers Union Byggnads, an LO member, against the Latvian company Laval un Partneri employing Latvian workers in a construction site in the city of Vaxholm, was unlawful. The ECJ judged that the blockade, in which other unions had also participated following unsuccessful negotiations to sign a collective agreement, had violated the EU principle of freedom to provide services and could not be justified on grounds of the public interest (EU Observer, 18 December 2007). Although the Court did not rule against the principle of collective action to avert social dumping, it asserted that a blockade of an unspecified duration in the absence of clearly set provisions was disproportionate. Prior to the final ruling, the issue had become intensely politicised. The dispute dates back to 2004, when Byggnads took action against Laval, and was strongly supported by both the SAP Government and LO. Svenskt Näringsliv had come under pressure from the labour movement when it was revealed that it had sought to avert Laval's eventual bankruptcy by offering financial assistance.

What is fundamentally at stake here concerns the Swedish system of collective bargaining and the application of EU law. Under the EC Directive on the foreign posting of workers adopted in 1996, employees posted abroad enjoy minimum standards of protection as laid out by the host state, either through legislation or collective agreement. At the time this appeared to be a confirmation of the Swedish model, verifying the legitimacy of the collective agreement system. However, it has been argued that the Directive's Swedish transposition in 1999 clashes with the EU principle of cross-border service provision (Woolfson and Sommers 2006: 59) and may not be applicable to EU firms. Laval had used the EC Directive in an earlier phase of the conflict, claiming that it was not mandatory to pay a minimum wage to its employees as Swedish legislation does not stipulate such levels, nor are they to be found in collective agreements.

The ECJ ruling has provoked a heated debate over the future of the Swedish model. Interestingly, both unions and employers have called for 
legislative action. While SN calls for limits to be placed on sympathy strike action, the LO has requested the amendment of the Posting of Workers Act to establish a level playing field for Swedish and foreign firms. Prior to the ECJ ruling, the LO and SN had sought to limit the disturbances caused by a possible 'Vaxholm effect' by signing an agreement 'recommended' to their members. According to that agreement, LO and SN members would adjust their collective agreements so that foreign companies temporarily joining an employer organisation of $\mathrm{SN}$ would be subject to legislation agreed between the social partners.

The challenges posed to the Swedish model following the ECJ ruling are numerous. To start with, the Vaxholm conflict highlights the frictions caused when a law-based juridical paradigm, as represented by the ECJ, conflicts with the collective agreements system reliant on encompassing unions and employers. If the government declines to amend the Posting of Workers Act, different companies will be subject to different legislation in the Swedish labour market, as Swedish legislation does not foresee the applicability of collective agreements beyond the sectors involved. This could, in turn, lead to higher levels of industrial action and productivity losses harming the Swedish economy. Second, the post-Vaxholm reality could mean higher wage differentials among but also between occupational categories, cancelling out the LO's recent advances. The welfare system would have to sustain higher demand, at a time when tax cuts for capital and wealth have been enacted by the centre-right government. Finally, the ECJ ruling offers a competitive advantage to employers prior to the commencement of negotiations on renewing the Saltsjöbaden agreement. The SN, LO and PTK will start negotiations on a new basic agreement that would take into account rapid changes in the labour market through Europeanisation and globalisation. Though their agenda is different, the two sides will seek to work out a compromise and confirm the sustainability of the Swedish model in the twenty-first century. An attempt to carve out a similar agreement previously ended in failure, but heightened levels of cooperation between the two sides offer grounds for more optimism this time round.

\section{Conclusion}

For the Swedish Social Democrats, the crisis of the 1990s was not merely an economic one. It was accompanied by the collapse of the old Swedish model and it questioned the viability of the progressive coalition centred on the party-union link. By the end of the 1990s, however, and due to the durability of the institutional resources at the disposal of the labour movement, combined with some shrewd policy moves on the part of the SAP, things 
improved. The party-union relationship, vital to maintain a comprehensive welfare regime and guarantee high-wage and work conditions, has picked up markedly, while the broad sketches of a new Swedish model have been developing since the signing of the Industrial Agreement. On the other hand, internal and external difficulties remain, and their consequences, if left unchecked, could be devastating in the long run.

Following the 2006 election defeat, Mona Sahlin became the first female SAP leader. Tainted by her role in the welfare cuts of the early 1990s as Labour Minister, Sahlin has made a triumphant return after she lost the first chance to lead the party in the mid-1990s due to a financial scandal. During 2007, the SAP has kept a low profile and has been largely absent from the political debate. The government's woes have helped the opposition parties to establish a commanding lead in the polls, and the SAP currently polls between 40 and 45 per cent of the vote. During 2007, the SAP has been clear in its condemnation of government policy, and Sahlin cowrote an article with the LO president promising to undo financial changes in unemployment insurance (Dagens Nyheter, 30 April 2007). On the other hand, the party is seeking to distance itself from the 'dependency culture' it allegedly cultivated and is likely to maintain the new, stricter rules on eligibility, along with a 'tougher' approach to school discipline. The SAP has joined forces with the Greens and the Left Party in attacking the government, while making common cause on issues such as climate change and civil rights. The departure of Persson has made collaboration with the junior opposition parties easier. At the same time, the Greens and the Left Party continue to maintain an intransigent anti-EU position that the SAP is unlikely to tolerate in a possible coalition government. What is more, the party leadership is closer to the Greens, but the rank and file would prioritise collaboration with the Left Party instead.

Swedish social democracy has some time until the next election to form a progressive party programme that clearly distinguishes it from the Moderates, and outlines the welfare and labour market changes necessary to maintain a competitive economy and a just society. This chapter has sought to emphasise that working with the unions remains the party's most valuable option. At a time of uncertainty and confusion, the Swedish labour movement cannot afford to fail in its mission. There is a good chance that it will not.

\section{Notes}

1 Interview with the Kommunal ombudsman, 16 September 2004.

2 Interview with the chief negotiator of the Svenskt Näringsliv in the European Federation of Enterprises UNICE, 18 August 2004. 
3 Interview with the LO public policy director, 1 September 2004.

4 Interview with the LO chief coordinator, Stockholm, 2 September 2004.

5 Interview with the ombudsman for SAP-LO relations, 24 September 2004.

\section{References}

Andersson, B. (2007) 'Rekordmånga flyr facket', Dagens Nyheter, 13 December.

Andersson, D. (2006) 'Arbetslöshetsförsäkringen omvandlas till socialbidrag', Dagens Nyheter, 17 November.

Andersson, J. (2006) 'Growth and security: Swedish reformism in the post-war period', in J. Callaghan and I. Favretto, Transitions in Social Democracy: Cultural and Ideological Problems of the Golden Age (Manchester: Manchester University Press).

Aylott, N. and Bolin, N. (2007) 'Towards a two-party system? The Swedish parliamentary election of September 2006', West European Politics, 30 (3).

Bäckström, U. (2007) 'A-kassan behöver konkurrens', Svenska Dagbladet, 22 October.

Bergström, H. (2007) 'Handelns jubel', Dagens Nyheter, 14 April.

Burkitt, B. and Whyman, P. (1995) 'Lessons from Sweden: full employment and the evolution of Keynesian political economy', Renewal 3 (1).

Callaghan, J. (2000) The Retreat of Social Democracy (Manchester: Manchester University Press).

EIROnline (2007) 'Unions criticise proposal to cut unemployment and sickness benefits': www.eurofound.europa.eu/eiro/2007/10/articles/se0710029i.htm (accessed 21 November 2007).

Elvander, N. (2002) 'The labour market regimes in the Nordic countries: a comparative analysis', Scandinavian Political Studies, 25 (2).

EU Observer (2007) 'Swedish trade unions lose EU labour case, 18 December': http://euobserver.com/9/25359 (accessed 19 December 2007).

Forsman, E. (2007) 'Trygghetsavtal ger arbetslösa nytt jobb', TCO-Tidningen, 8 March.

Gatu, H. (2007) ‘Höjda lägstalöner byter trend', Dagens Arbete, 19 March.

Iversen, T. (1996) 'Power, flexibility, and the breakdown of centralised wage bargaining: Denmark and Sweden in comparative perspective', Comparative Politics, 28 (4).

Johansson, A. L. and Magnusson, L. (1998) LO andra halvseklet. Fackföreningelsen och samhället (Uddevala: Atlas).

Kjellberg, A. (1998) 'Sweden: restoring the model?', in A. Ferner and R. Hyman (eds), Changing Industrial Relations in Europe (Oxford: Blackwell).

LO (1991) Rättvisa i vågskålen (Stockholm: LO).

LO (2000) Landsorganisationens 24:e ordinarie kongress 2-6 September 2000 (Stockholm: LO).

LO (2001) Rekommendation till förbunden med gemensamma krav inför Avtal 2001 (Stockholm: LO).

LO (2004) 'Rate of trade union organisation in Sweden': www.lo.se/home/lo/ home.nsf/unidView. 
Möller, T. (1999) 'The Swedish election 1998: a protest vote and the birth of a new political landscape', Scandinavian Political Studies, 22(3).

OECD (2001) Economic Survey Sweden (Paris: OECD).

Pestoff, V. A. (1995) 'Towards a new Swedish model of collective bargaining and politics', in C. Crouch and F. Traxler (eds), Organised Industrial Relations in Europe: What Future? (Aldershot: Averbury).

Pontusson, J. (1995) 'From comparative public policy to political economy: putting political institutions in their place and taking interests seriously', Comparative Political Studies, 28 (1).

Pontusson, J. and Swenson, P. (1996) 'Labor markets, production strategies, and wage bargaining institutions: the Swedish employer offensive in comparative perspective', Comparative Political Studies, 29 (2).

Ryner, M. J. (2002) Capitalist Restructuring, Globalisation and the Third Way: Lessons from the Swedish Model (London: Routledge).

Sahlin, M. and Lundby-Wedin, W. (2007) 'A-kassan ska återstellas till 80 procent av lönen', Dagens Nyheter, 30 April.

SAP (1981) Framtid för Sverige (Stockholm).

SAP (1985) Partiprogram (Stockholm).

Swank, D. (2002) Global Capital, Political Institutions and Policy Change in Developed Welfare States (Cambridge: Cambridge University Press).

Thelen, K. (1993) 'West European Labor in transition: Sweden and Germany compared', World Politics, 46 (1).

Tidningarnas Telegrambyrå (2007) Pensionsavtal för arbetare klart, 16 April.

Tidningarnas Telegrambyrå and Rönnqvist, A. (2007) Hård kritik mot försäkringsförslag, 22 December.

Traxler, F. (1995) 'Farewell to labour market associations? Organized versus disorganized decentralization as a map for industrial relations', in C. Crouch and F. Traxler (eds), Organized Industrial Relations in Europe: What Future? (Aldershot: Avebury).

Whyman, P. and Burkitt, B. (1993) 'The role of Swedish employers in restructuring pay bargaining and the labour process', Work, Employment and Society, 7 (4).

Woolfson, C. and Sommers, J. (2006) 'Labour mobility in construction: European implications of the Laval un Partneri dispute with Swedish labour', European Journal of Industrial Relations, 12 (1). 